ljtihad, Jurnal Wacana Hukum Islam dan Kemanusiaan

Vol. 16, No. 2 (2016), pp. 281-296, doi : 10.18326/ijtihad.v16i2.281-296

\title{
In search of Islamic view of justice on women testimony
}

\author{
Husni Mubarrak \\ Fakultas Syari'ah dan Hukum Universitas Islam Negeri (UIN) Ar-Raniry Banda Aceh \\ E-mail:husnilatie@yahoo.com
}

DOI: 10.18326/ijtihad.v16i2.281-296

The most current challenges faced by Moslem in terms of Islamic religious discourse are religious interpretation on gender equality on position men and women. Among long crucial debate related to the issue is position of men and women in testimony, when the place of two women witnesses which are conceived equal to one man. It seems an ambivalent takes place regarding Islamic religious interpretation when many verses mentioned in the Quran and some hadiths have declared explicitly the same shared opportunity and capacity as well as mutual relation between men and women as vicegerents (khalifah) of God on the earth, meanwhile in the practice which inherited over centuries demonstrated inequality of men and women. This contrast, however, ultimately indicates a tension between Islam that ethically egalitarian and historically determined. This article tries to seek an Islamic view of justice on women testimony by arguing the importance of contextualizing interpretation by revitalizing appropriate maxim of Quran exegetes and up grading maqāsid studies in order to find a more equal and just religious interpretation on women in Islam.

Di antara tantangan terbesar yang dihadapi Muslim saat ini terkait diskursus keagamaan Islam adalah pemahaman keagamaan tentang persamaan gender antara pria dan wanita. Termasuk perdebatan panjang dalam masalah itu adalah dalam persoalan kesaksian, yang mana kesaksian dua wanita kerap diposisikan setara dengan seorang pria. Kelihatannya terjadi ambivalensi di sini manakala banyak ayat Al-Qur'an dan hadits menyebutkan secara terang-benderang kesamaan kesempatan dan kapasitas yang dimiliki oleh pria dan wanita dalam mengemban tugasnya sebagai khalifah di muka bumi. Sementara dalam tataran praktis, seperti yang telah terwariskan sepanjang abad, menampakkan ketidaksetaraan antara pria dan wanita. Anomali ini, pada gilirannya, menunjukkan tekanan yang saling tarik-menarik antara Islam yang secara etis sangat egaliter dengan historisitas yang kian determinan. Artikel ini berupaya mencari pandangan Islam tentang keadilan terkait kesaksian wanita berargumenkan pentingnya kontekstualisasi interpretasi dengan merevitalisasi kaidah-kaidah penfasiran Al-Qur'an yang lebih sesuai serta penekanan pada urgennya 
ljtihad, Jurnal Wacana Hukum Islam dan Kemanusiaan, Volume 16, No. 2, Desember 2016: 281-296

studi maqāsid dalam rangka menemukan interpretasi keagamaan yang lebih sesuai, adil dan setara terkait kedudukan wanita di dalam Islam.

Keywords: Women testimony; Gender equality; Islamic legal reasoning; Contextualizing interpretation, Maqāisid Sharīah.

\section{Introduction}

Among long crucial debate regarding Islamic religious interpretation, related to position of men and women in testimony, is the place of two women witnesses which are conceived equal to one man. Many reasons are adopted and subjected to justify this inequality circumstance, either with literally some proof interpretations laid on Quran verse and Prophet's traditions (hadiths), or psychological and sociological reasons of intellectual deficiency, less reliable until less credible of testimony belongs to women rather than to those the men.

The debate, however, emerged from the interpretation of the verse in Quran (2:282) which seems stated explicitly, when Allah commands the believers to bring two men witnesses, or in the absence of two men, a man and two women, to witness certain types of contracts, because the verse talks about financial transaction. Two words that come in the verse dealing with women condition, which literally in Arabic meant and understood as "to forget" (an tadhilla) and "to remember" (fa tudhakkira), have been looked as the justification that women deficiency required the presence of a man and two women witnesses, in case of the absence of two men witnesses, in any financial transactions (al-'Alwani, 1996: 174).

This kind of interpretation on inequality men and women is appeared, recited, inherited generation by generation over centuries and then developed which later accepted as taken for granted and became "a should be" interpretation within Islamic discourse in Moslem society since long time ago. Meanwhile, one thing more likely overlooked that there are many verses mentioned in the Quran and some hadiths which have declared explicitly the same shared opportunity and capacity as well as mutual relation between men and women as vicegerents (khalifah) of God on the earth (Al-Ghazali, 34-37).

The inequality circumstance finally led us to a more curious question on how should the verse on women testimony be understood and interpreted in terms of position both men and women, especially in the current contemporary time which demands a more equal and 
egalitarian condition between men and women? Is the number of witness becoming important as the essence of the message or is there anything else core value of the verse? What kind of attempt could be exerted in order to bridge contradict interpretation between this verse on women testimony and other verses in Quran and ḥadiths (Pophet's tradition) which stated explicitly the same status of all believers, men and women? Is the verse of testimony being reasonable (ta'aqquīi) or should be obeyed for worship purposes only (ta'abbudî̀? Could the verse on women testimony be contextualized upon condition and situation?

Although many verses in the Quran clearly mentioned that women who are believers have the same shared chance and being as the partners of men in many various situations, but the interpretation that based on inequality of number referred as a condition of deficiency and capacity to remember belongs to women is still strongly being the mainstream. This circumstance, thereby required at the last, the presence of two women, such witness as you approve of, lest one of the two (women) err, and then the other will remind her.

Nevertheless, the view on women testimony which has been shared among Muslim jurists and scholars since classical era to modern doesn't required the reasons and the methods of Quran verse interpretation alike. Turning from this point, it becomes more significance to know more on the methods and reasoning process of Quran verse on women testimony, used by Muslim scholars, which ultimately leads at the last to a comprehensive understanding of justice in Islam related to gender equality.

This paper will examine the view of Islam on justice dealing with gender equality issue by putting Quran verse exegetes on women testimony (2:282) as the focus by using bibliography study. To equip, this article will be enriched by literature study on the background of the verse revelation (asbāb nuzūi) and on what the verse discusses about, with a little consideration to the books of Quran exegetes that are mostly written by men either in the classical time or contemporary era as the compared references. Equally important, to know more on coherently thinking and consistently reasoning used by Muslim jurists in interpretation process, the maxims in Quran exegetes and Islamic legal reasoning will be examined to get a deeper understanding of the issue, particularly in terms of equal relation of men and women.

I argue that literally Quran verses interpretation on women testimony mostly ignored the core value and ethical equality of the principles of Islam. Thus, in search of the core 
ljtihad, Jurnal Wacana Hukum Islam dan Kemanusiaan, Volume 16, No. 2, Desember 2016: 281-296

view of Islam on justice regarding women testimony should be read and contextualized in various approaches to get a more comprehensive understanding of Islam related to the issue.

To this end, the second section will provide literature review on women testimony verse exegetes and some current contemporary studies on the issue. The third section will discuss Islamic legal reasoning to find appropriate method within Islamic law perspective dealing with Quran verse interpretation, while the fourth section will present some attempts done by Muslim scholars either in medieval time or contemporary regarding women testimony verse interpretation, continued by fifth section in search of a new interpretation on the verse and at the last will be closed by concluding remark.

\section{On women testimony verse exegetes (2:282): literature review}

It is no doubt that Islam, as a revealed religion, has put the core value within its principles on brotherhood and equality related to the position of men and women. That value could be concluded and also reflected from many verses in the Quran which obviously mentioned that women who are believers have the same shared chance and being as the partners of men in many various situations and different aspects of life. This value which strongly based and rooted to the main sources of Islam, i.e. Quran and ḩadith, has broadly been accepted and applied among Muslim society in the time of revelation to abolish the customs, traditions and inequality circumstances of pre-Islamic Arab society (al-'Alwani, 1996: 174-5).

That kind of just Islamic teachings is important to be mentioned here that Islam has its own revealed comprehensive view in terms of defining justice regarding position of men and women in society. This view, however, still be preserved and maintained within the Moslem society framework until inequality interpretation of Quran came into surface and became the mainstream interpretation by arguing with some proofs and evidences, quoted from Quran for then perceived as a legitimated authority to give the right meaning and interpretation of Quran (Fadl, 2003: 98-140).

This latter kind of interpretation has also been tried to be justified and corroborated with some limitations perceived belong to women in terms of intellectual deficiency, less reliable, less credible in certain situation which could be categorized as some inherited psy- 
chological and sociological prejudices among society. To support this view, some verses in Qur'an such as shown in the verse (2:282) regarding women testimony which required two women and one man, in case of the absence of two men as the witness, was used to justify that such limitation as the obstacle of an equal condition between men and women.

In fact, inequality in number regarding women testimony of two women equal to one man, as stated above, actually derived from literally interpretation from the verse so-called verse of debt (- ayat al-dayn) in Quran (2:282). Within interpretation process, one thing couldn't be dismissed that the understanding of a text has more to do with the context surrounding the text when it appeared than with the text itself. Many Muslim jurists categorized the verse as recommended or merely instructional (irshäd) and without legal import rather than an obligatory or $\bar{j} j \bar{a} b$ (al-'Alwani, 1996: 173). The whole meaning of the verse as follow:

"O, you who believe! When you contract a debt for a fixed term, record it in writing. Let someone (learned) write down in justice. No person (able to write) should refuse to write as God has taught him, so let him write, and let him who incurs the debt dictate, and let him observe his duty to God, his Lord, and diminish not thereof. But if he who owes the debt is an ignorant or feeble-minded person, or unable himself to dictate, then let the guardian of his interests dictate in justice. And call to witness, from among your men, two witnesses. And if two men be not (at hand) then a man and two women, of such as you approve as witnesses, so that if one (woman) errs (through forgetfulness) the other will remember. And the witnesses must not refuse when they are summoned. Be not averse to writing down (the contract) whether it is small or great, with (record of) the term thereof. That is more equitable in the sight of God and better for testimony, and the best way of avoiding doubt between you except only in the case when it is actual merchandise that you transfer among yourselves from hand to hand. In that case it is no sin on you if you write it not. See that witnesses are present when you sell to one another, and let no harm be done to the person who wrote or the witness. If you do (harm to them) lo! It is a sin in you. Fear God, and God will teach you. And God is Knower of all things" (Pickthall, 1930: 2:282).

Among the reasons to be used as justification regarding women testimony in the verse, it is understood and looked at the stressing point of the message explicitly for seeking testimony from two women in place of the testimony of one man, by saying, "...if two men be not (at hand) then a man and two women, of such as you approve as witnesses, so that if one (woman) errs (through forgetfulness) the other will remember". 
ljtihad, Jurnal Wacana Hukum Islam dan Kemanusiaan, Volume 16, No. 2, Desember 2016: 281-296

It is not easy to define when exactly the literally interpretation of "two women equal to one man" regarding testimony matter, arose and eventually accepted as a final decision among Muslim jurists within Islamic discourse, as performed in many classical Muslim works. Oppositely, different understanding on the verse was addressed by some contemporary Muslim scholars to reject such literally interpretation attempt that loosen the essence of Islamic justice by understanding the core message in Islam on equality of men and women. Other critiques also delivered in different senses dealing with imbalance position and power of men and women within Islamic society, as demonstrated through some contemporary works and interpretations.

It is necessary to mention here different views aroused by some contemporary modern Muslim scholars regarding verse interpretation. According to a Muslim feminist, Amina Wadud, the condition of inequality of men and women could be not separated from the traditional verse-by-verse method of Qur'anic exegesis (tafsir bil ma'th $\bar{u}$ ) which along dominated by male practitioners, thus has marginalized female experiences in understanding revelation (Wadud-Muhsin, 1994: 1-2).

Similarly, such interpretation of inequality has also broadly criticized by Mernissi who pointed out that criticisms of the religious scholars are not so much that they found their own misogynism confirmed by God revelation, but rather they failed in creating "principles, laws or axioms that would allow the reader to distinguish the structural from the circumstantial" (Mernissi, 1987: 127). To agree or disagree, both comments by Wadud and Mernissi, however, shown us-to somehow-male-dominate interpretations among the Muslim jurists and scholars in classical era which almost ignored the ethical equality of the principles of Islam.

Those comments, whether agreed or not, could also be confronted to a study finding by Taha Jabir al-'Alwani who did bibliography research and found that the method and the way of Quranic interpretation on the word reminding in the verse was interpreted that a woman who gives testimony, and who is helped through another woman's reminding, becomes legally equal to a man. This commentator interpretation, according to Al-'Alwani, could be traced back to classical era such as Sufyan ibn 'Uyaynah (d. 814 AD/ 198 AH). Meanwhile, other commentators including Al-Thabari (d. 923 AD/ 310 AH) who wrote 
the earliest book of Quran exegetes on verse-by-verse method (tafsìr bil ma'thür), rejected the view that based on the other's reminding has the effect of causing the first woman to remember what she had forgotten. The generation of Quranic commentators who came after Al-Thabari did not go beyond these two positions, namely only the woman remembered after being reminded legally equal to one man; or another view that the combination of the forgetful woman and the reminding woman could then be legally equal to one man who remembers (al-'Alwani, 1996: 178).

This interpretation of inequality ultimately indicates a tension between Islam that ethically egalitarian and historically determined. This statement could also be confirmed to a study conducted by Mohammad Fadel on the production, reproduction and application of medieval Islamic law on the gender equality issue as it appears in the works of Sunni jurists from post-Ayyubid $12^{\text {th }}$ century. The study was done in searching the gender based distinctions established in the medieval Islamic law of testimony through the arguments made by Al-Qarafi $\left(13^{\text {th }}\right.$-century Maliki jurist) and al-Tarabulusi $\left(15^{\text {th }}\right.$-century Syrian Hanafi jurist). The study finding showed that despite explicitly the reports of men and women are equally probative in front of the court, but the law refused to consider an individual woman's statement a proof (bujjah) because the law obliged her to stay at home in order to avoid social corruption and disorder. One another reason which is perceived as corroboration the former, that women are inherently deficient in reason and religion (al-nisä', näqicât al-'aql wal $\overline{d i n})$. Thus, the women in many circumstance, ultimately become politically marginalized social actors (Fadel, 1997: 186-194).

The same conclusion but in different sense regarding imbalance position between men and women is also delivered by Abou El Fadhl, in terms of defining religious authority and religious authoritarian regarding women manners and activities in the public sphere. By examining the fatwa (non binding Islamic legal opinion) issued by CRLO (Council for Scientific Research and Legal Opinions), a religious Islamic institution in Kingdom of Saudi Arabia, Abou El Fadhl criticizes that many fatwas issued dealing with women issue are mainly based on misogynism rather than the finest understanding of Islamic legal reasoning which are corroborated by interpretation of evidences and proofs. 
ljtihad, Jurnal Wacana Hukum Islam dan Kemanusiaan, Volume 16, No. 2, Desember 2016: 281-296

These researches findings get its significance to demonstrate because either in classical or modern era, mostly interpretation on women testimony is alike, as what we will see next in some Quran exegetes. The idea reasons which have been shared over centuries back to the given meaning of the verse (2:282) on word (an tadhilla) which literally in Arabic meant and understood as "to forget" and word (fa tudhakkira) as "to remember" that indicates at the last the women are inherently deficient in reason and religion (naquicat al-'aql wal din). The reasons which have been argued by those are various, as well. The theologian Fakhr al-Din al-Razi (d. 1210 AD) explained that the woman's different biological nature made her more prone to forget than a man (Al-Razi, 1981: 7/122-123). A well-known Mu'tazilate thinker and commentator of the Quran, Zamakhsyari (d. $538 \mathrm{AH}$ ), wrote the same reason that possibility to forget as a deficiency in women so that need two women if one (woman) errs the other will remember. In addition, Zamakhsyari quoted Abu Hanifah (founder of Hanafi school in Islamic jurisprudence) that women testimony which supported by men are accepted as long as it doesn't related to Islamic penal law such as qicac (murder) and buudüd (Zamakhsyari, 2009: 156). Similarly, for the modern Quran exegetes works, Sayyid Qumb (d. 1966 AD) through his masterwork, Fī 'ilal Qur'an, argued that the requirement of two women presence is more caused by woman's psychology, specifically her motherly instincts, that prevented her from possessing the objectivity necessary for a witness (Qumb, 2003: 335-336).

Still in the verse interpretation, a rational question arose and addressed by Ibnul 'Arabiy (D. 543AH/1148 AD) in his work, Aḅkamul Qur'an. After mentioning the comments on the verse as mentioned above, he asked rhetorically, "What if there is one woman and one man, so that the man can remind her if she forgets?", "What is the wisdom in that?", But immediately, he goes on to nullify the question by stating: "The answer is that Allah legislates what He wills, and He knows better what wisdom lies behind His legislation. It is certainly not essential that His creation should know and understand that the wisdom in what he legislates for their betterment and welfare" ('Abdillah Ibn al-'Arabiy: 1/337). So, it could be summed up shortly, that after proposed this rhetorical question, Ibnul 'Arabiy then arrived to a conclusion that this verse of women testimony close to be obeyed for worship pur-

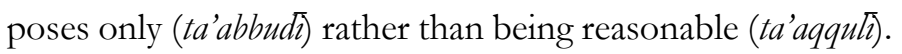


Different interpretation on the verse seems came into the surface when the celebrated Muslim reformer from Egypt, Muhammad 'Abduh (d. 1905 AH) with his student and his disciple, Muhammad Rasyid Ridha (d. 1935 AH) rejected the requirement of two women witnesses based on the different nature of men and women. Through his masterwork, Tafsir al-Manār, he argued that both men and women have the same capacity for remembering and forgetting. Thus, the different economic roles of men and women in society made each vulnerable to forgetting those things that were not part of their (men or women) daily experience (Rasyid Ridha, 1367: 3/122-123).

In similar to Abduh's view, equally important to be mentioned here what has been exerted by a well-known contemporary Muslim reformist from Tunisia, Muhammad AlThahir Ibn 'Ashur (d. 1973 AH) who broadly known as an Ulama Maqậ̣id (the Muslim scholar whose expert on the purposes of sharia), tried to analyzed the verse by using a methodology in ușul fiqh (Islamic jurisprudence principles) to find the basis of the verse's circumstantial context ('illah). He found that it doesn't mean that women testimony is not accepted until it couldn't presence the main requirement of two men witnesses. The purpose of sharia on the issue of two women witnesses is for the simplicity and easiness (tawsi'ah) of humankind in any financial transactions by engaging women within, unlike the pre-Islamic Arab traditions (ibn 'Ashur, 1984: 3/108).

Various different interpretations above by Muslim scholars shows in very simply that the Quran verse on women testimony is closed to be a thinkable matter (al-mumkin al-tafk $\bar{i}$. fibi) - to borrow Arkoun's terminology — that the reasons behind the verse still possible to be looked for. It doesn't purely indicate the verse as a permanent thesis (qam'iyya $\bar{t}$ ) that couldn't be reasonable. The testimony itself is quite related to Islamic law domain, so that become necessary to discuss here the methods and reasoning of Islamic law and jurisprudence, in terms of understanding the corridor, purpose and scope of the verse regarding women testimony.

\section{Islamic legal reasoning}

In the field of Islamic law and jurisprudence studies, an important process that could be not dismissed by the actor (faqīh) who engages in searching and producing certain decisions 
ljtihad, Jurnal Wacana Hukum Islam dan Kemanusiaan, Volume 16, No. 2, Desember 2016: 281-296

on Islamic law is legal reasoning that should be undergone within the process, compiled in ushül fiqh (Islamic jurisprudence principles). There are, at least, three methods with its various tools of each method, that recognized and applicable within ushül figh, namely: bayani $\bar{i}$, this reasoning process that emphasizes on the language and semantic approach to figure out the real meaning (haqiquah lughawiyyah) or metaphor one (ḥaqiqah majäziyyah) particularly in Arabic in understanding any comments or prohibitions of God which mentioned in the main sources, Quran and hadith. The second method is known as ta'ili $\bar{l}$ which means an exertion to find the basis of the verse's circumstantial context ('illah) whether in Quran or hadith. In certain verses and conditions in Quran and ḥadith, 'illah is mentioned explicitly or implicitly which needs at the last to a long deep attempt and journey by a faqīh to search the main reasoning of God's legislation. And the last but not the least, the method istishla $\bar{b} \bar{i}$ as the reasoning process done by the faqīb to seek the common principles in Islam as mentioned in Quran and hadith to realize graceful, kindness, wisdom, for humankind as the universal message of the Islamic sharia law in realizing interest (maslahat) and avoiding any harm matters (Al-Duwaylibi, 1995: 347-361).

According to discussion above on women testimony as performed in classical Muslim works, mostly interpretations made in Quran verse exegetes (2:282) based on bayani $\overline{\text { method }}$ by putting literally meaning of word "an tadhilla" that understood as "to err and to forget" and another one, (fa tudhakkira) which meant "to remember". Such attempt also noticed and confirmed by Al-Alwani that "according to Arabic Lexicon, the underlying meaning of word dalal in the verse is "absence". Later, the word was used to indicate any turning from the right way, whether intentionally or otherwise. The word came to be used in the sense of "to forget", for the reason that one who forgets is one for whom the right way is absent. The wisdom in the Quran's choice of this word, rather than one usually chosen to mean "to forget" (nisyan) or "to err" (khatha) is perhaps that meaning of daläl is broader and more comprehensive than the other two, as a mistake in testimony may be either intentional or unintentional." (al-'Alwani, 1996: 178).

Moving from semantic approach to find the real word meaning of the verse, it is a serious attempt, as well, to analyze the verse by using ta'titi method to find the basis of the verse's circumstantial context ('illah) as shown by the work of Ibn 'Ashur. According to 
'Ashur, it doesn't mean that women testimony is not accepted until it couldn't present the main requirement of two men witnesses. So that he emphasized that the purpose of sharia on the issue of two women witnesses is for the simplicity and easiness (tawsiab) of humankind in any financial transactions by engaging women within, unlike the pre-Islamic Arab traditions.

Turning from this point, it is necessary to redefine this verse on women testimony whether

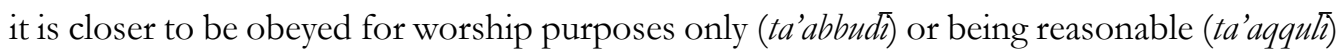
regarding inequality number of witnesses between men and women, so that it could be understood later contextually in a broader scale, in order to find the core message behind the verse and ultimately arrive at the spirit of justice in Islam.

\section{Contextualizing interpretation}

Islamic law may have been derived ultimately from revelation, but when it tried to be applied within society, it was no longer being interpreted solely with reference to revelation. It should be merged with the condition that surrounding the community where it be implemented. This way is known as a mix-merge process to get a more contextual interpretation by interpreting revelation ( $f a h m$ nushîsh) and interpreting reality (fiqh al-wâqi) on how it could be applied simultaneously (Mubarrak, 2012: 5).

As mentioned in many Quran verse exegetes regarding women testimony above, mostly commentators and interpreters opined inequality of men and women based on abilities and propensity to forget of women by putting literally meaning of word "an tadhilla" in the verse that understood as "to err and to forget" and another one, (fa tudhakkira) which meant "to remember". This kind of interpretation seems on the contrary with the main message in Islam on equality gender between men and women which at the last indicates a tension between Islam that ethically egalitarian and historically determined (Fadel, 1997: 199).

To prove this statement, it is important to be mentioned here that through historical account within Muslem society, it looks an ambivalent occurs-whether intentionally or unintentionally — to differ and make separation and distinction what later perceived as political speech (syahädab) and normative speech (riwäyah). In terms of riwäyah, among the first 
ljtihad, Jurnal Wacana Hukum Islam dan Kemanusiaan, Volume 16, No. 2, Desember 2016: 281-296

generation of Muslims, there were several women who were involved in both the transmission of religion as well as the development of its legal doctrine. To mention one of the most prominent of these women was 'Aisyah bint Abu Bakr, the youngest wife of the Prophet Muhammad and who also recited among the most many of hadith. Among the main requirement in reciting hadith and then to be authentically acceptable is credible individual (' $a d l$ ) as the qualified narrator. This strict requirement, however, has been fulfilled by 'Aisyah alone, so that her riwayah was accepted. On the contrary, the requirement of testimony on political speech (syahädah) as understood on the verse must put two women equal to one man based on women deficiency, less reliable, less credible and prone to forget which are close to sociological condition rather than capacity and ability that belonged to.

Although this view could be not generalized, but it is important to notice here based on study done by Fadel that along Islamic jurists history, we can find a few but important jurists, namely the Syrian Hanbalites Ibn Taimiyya (d. 1327 AD) and Ibn Qayyim al-Jawziyya (d. 1350 AD) who rejected this kind of distinction between political speech (syahädah) and normative speech (riwayab). Based on the fact that the women's transmission of Prophetic reports was admissible, the purpose of testimony was to gain truth about a past even. Therefore, if a woman was believed to be reliable in her testimony regarding religious matter, she must be assumed, all things being equal, also to be reliable in other areas of life. To strengthen the view, it should be taken into account that testimony of men or women should be ruled as long as that evidence was likely to be true and trustworthy, regardless of their gender. For this reason, both Ibn Taimiyya and Ibn al-Qayyim al-Jawziyya rejected the two women equal to one man rule that lay at the heart of discrimination against women's testimony. Whenever a woman has shown herself to be credible, her evidence should be admitted (Fadel, 1997: 196-198).

The contrast interpretation among Muslim jurists as mentioned above has shown to us that how some respected Muslim scholars attempted to put words in the Quran-to somehow-for the sole purpose of supporting prevalent social ideas, so that gender biased interpretation hardly avoided (al-'Alwani, 1996: 180-181). Meanwhile the core message and value of Islam as stated in Quran and hadith regarding position and condition of men and women explicitly emphasizing on mutual relation and gender equality which have been the 
reasons what Islam revealed for.

To sum up, in the last, the Quran verse exegetes interpretation on women testimony seems need to be contextualized to find a more reasonable spirit of Islam on justice of equality gender, particularly dealing with women testimony.

\section{In search of a new interpretation}

How to read Quran in the current context which appropriate, acceptable, reasonable and applicable to the contemporary time are the real challenges faced by Muslim in modern era. There are many issues which mentioned in Quran related to religious matters come into the surface at the present time seems needed to be reinterpreted, particularly on gender equality issue.

The inquiry emerges for instance, on how to interpret the meaning of equality and justice on Quran verse regarding two women equal to one man in testimony. The equality demand here absolutely doesn't mean how to make a shift and change inequality number paradigm to becoming directly equal one woman one man. The problem is not that easy. To make valuable change on Quran interpretation is not only change in meaning, but it is also strictly related to on how is paradigm constructed, what maxims dealing with Quran interpretation being used and how is legal reasoning been preserved to explain such shifting paradigm?

There are few maxims have been made, agreed and examined scientifically by Muslim commentators within Quran study that could be applied in Quran verse interpretation process, especially to the study on the background of the verse revelation (asbāb nuгūi). Among others is "The conclusion is made by a certain cause, not by general word meaning" (al-ibratu bi khușus sabab, là bi 'umūm lafdh). Based on this maxim, it becomes an important thing to be questioned here, could the Quran verse on women testimony be understood and read in the spirit of equal number by putting an equal meaning that whenever a woman has shown herself to be credible and reliable as the main requirement, her evidence and testimony should be admitted. Do women have the same chance and opportunity like men regarding testimony as long as they have required credible and reliable qualification? If so, to what extent it could be applicable in various religious and legal matters? It will be a 
ljtihad, Jurnal Wacana Hukum Islam dan Kemanusiaan, Volume 16, No. 2, Desember 2016: 281-296

long journey to elaborate more and strengthen such opinion which should be corroborated with sufficient arguments and proofs, as well, so that it can be responsible generalized scientifically.

Another way or method that can be proposed in searching of a new interpretation on the issue is by upgrading the maqāisid (purposes of sharia) discipline as the most valuable study within current Islamic sharia law studies to seek the wisdom, object, purpose, maslahat (interest), goodness and gracious for humankind of each God's sharia legislation either in Quran or hadith.

Many have done and conducted regarding maqașid studies in this contemporary era especially after the era of Ibnu 'Ashur. In terms of women testimony, according to 'Ashur, the Quran verse is still reasonable; so that he emphasized that the purpose of sharia on the issue of two women witnesses is for the simplicity and easiness (tawsi'ab) of humankind in any financial transactions by engaging women within, unlike the pre-Islamic Arab traditions.

For the present current maqạsid studies, there are various attempts have been done by maqāsid scholars such as demonstrated by Ahmad Raisuni in order to get the core purpose and wisdom of any God's legislation in sharia law by differentiating what is the should purpose literal meaning (maqăsid khimāb) from what could be the secret and purpose of that God's legislation? (Raisuniy, 2014: 11-21). However, such methods still should be exerted more continuously in order to find acceptable, reasonable and applicable to the contemporary time on women testimony in order to find a more just and equal interpretation within Islamic view.

\section{Concluding remark}

I began this article with the statement that the place of two women witnesses which are conceived equal to one man regarding Islamic religious interpretation is among long crucial debate within Muslim jurists and commentators. The debate itself emerged from the interpretation of the verse in Quran (2:282) which seems stated explicitly, when Allah commands the believers to bring two men witnesses, or in the absence of two men, a man and two women, to witness certain types of contracts, because the verse talks about financial transaction. Two words that come in the Quran verse broadly discussed dealing with women 
condition, which literally in Arabic meant and understood as "to forget" (an tadhilla) and "to remember" (fa tudhakkira). Mostly commentators and interpreters opined inequality of men and women based on abilities and propensity to forget of women by putting literally meaning of word "an tadhilla" in the verse that understood as "to err and to forget" and another one, (fa tudhakkira) which meant "to remember". This kind of interpretation seems on the contrary with the main message in Islam on equality gender between men and women. Many verses mentioned in the Quran and some ḩadith have declared explicitly the same shared opportunity and capacity as well as mutual relation between men and women as vicegerents (khalifah) of God on the earth. This contrast, however, ultimately indicates a tension between Islam that ethically egalitarian and historically determined.

An ambivalent view regarding women testimony-whether intentionally or unintentionally-also can be seen when an attempt arose to differ and make separation and distinction what later perceived as political speech (syahädab) and normative speech (riwāa terms of riwayah, among the first generation of Muslims, there were several women who were involved in both the transmission of religion as well as the development of its legal doctrine. To mention one of the most prominent of these women was 'Aisyah bint Abu Bakr. Among the main requirement in reciting hadith and then to be authentically acceptable is credible individual (' $a d l$ ) as the qualified narrator. This strict requirement, however, has been fulfilled by 'Aisyah alone so that her riwayah was accepted. On the contrary, the requirement of testimony on political speech (syahädah) as understood on the verse must put two women equal to one man based on women deficiency, less reliable, less credible and prone to forget which are close to sociological condition rather than capacity and ability that belonged to.

Equally important to be added here as the concluding remark that I also have proposed two methods, namely: revitalizing an appropriate maxim of Quran exegetes regarding women position in Islam and up grading maqāsid studies in searching a more just and equal interpretation regarding women testimony based on Islamic view. I suggest for following research and study emphasizes on an applied reconstruction regarding Islamic legal reasoning in terms of equal interpretation between men and women. 
ljtihad, Jurnal Wacana Hukum Islam dan Kemanusiaan, Volume 16, No. 2, Desember 2016: 281-296

\section{Bibliography}

Al-'Alwani, Taha J., "The Testimony of Women in Islamic Law”, The American Journal of Islamic Social Sciences, 13/2, 1996.

'al-'Arabiy, Abu Bakar Muhammad bin Abdillah Ibn. Aḅkāmul Qurān. Beirut: Dâr al-Kutub al-'Ilmiyyah, n.a.

Al-Duwaylibî, Muhammad Ma'rūf. al-Madkhal ilā 'Im Ușūl Fiqh. Cairo: Dâr Shawwāf li alNashr wa al 'Tawzì', 1995.

El Fadl, Khaled Abou. Speaking in God's Name - Islamic Law, Authority and Women. Oxford: Oneworld Oxford, 2003.

Fadel, Mohammad, "Two Women, One Man: Knowledge, Power, and Gender in Medieval Sunni Legal Thought”, International Journal of Middle East Studies, 29/2, 1997.

Al-Ghazali, Muhammad. Qaḍayà al-Mar'ah bayn al-Taqâlid al-Rākidah wa al-Wấidah. Cairo: Dār el-Shurūq, n.a.

Al-Rāzi, Fakhr al-Dīn. Mafätị̧ul Ghayb. Beirut: Dār al-Fikr, 1981.

'Ashur, Muhammad Al-Thahir Ibn. Tafsìr al-Tahririr wa al-Tanwir. Tunisia: Dār Tünisiah li alNashr, 1984.

Mernissi, Fatima. The Veil and the Male Elite. New York: Addison-Wesley, 1987.

Mubarrak, Husni. Figh Islam dan Problematika Kontemporer. Banda Aceh: NASA \& Ar-Raniry Press, 2012.

Pickthall, Marmaduke. The Meaning of the Glorious Quran. N.p.: n.pub., 1930.

Qammān, Mannā'. Mabāhits fi 'Ulum al-Qur'ān. Cairo: Maktabah Wahbah, 2000.

Qumb, Sayyid. Fi 'ilal al-Qur'ān. Cairo: Dār el-Shurūq, 2003.

Raisūni, Ahmad. Muḥādarah fi Maqāsid Sharīah. Cairo: Dār al-Kalimah, 2014.

Ridha, Muhammad Rasyid. Tafsir al-Mañar. Cairo: Dār al-Manār, 1367 AH.

Wadud-Muhsin, Amina. Quran and Woman. Kuala Lumpur: Penerbit Fajar Bakti Sdn. Bhd., 1994.

Zamakhsyari. Tafsìr al-Kashshäf 'an Haqà'iq Tanzil wa 'Uyūn al-Aqāwìl fi Wujūh al-Ta'wīl. Beirut: Dâr el-Ma'rifah, 2009. 